Jurnal Penelitian Perawat Profesional

Volume 3 Nomor 1, Februari 2021

e-ISSN 2715-6885; p-ISSN 2714-9757

http://jurnal.globalhealthsciencegroup.com/index.php/JPPP

\title{
EFEK GELOMBANG ELEKTROMAGNETIK TELEPON SELULER PADA KUALITAS SPERMA
}

\author{
Devi Rahmadiani \\ Fakultas Kedokteran, Universitas Lampung, Jl. Prof. DR. Ir. Sumatri Brojonegoro No.1, Gedong Meneng, \\ Kec. Rajabasa, Kota Bandar Lampung, Lampung, Indonesia 35145 \\ devi.rahmadiani@gmail.com (+62 81646122973)
}

\begin{abstract}
ABSTRAK
Pemakaian telepon seluler semakin bertambah tiap tahunnya. Tercatat bahwa jumlah telepon seluler yang beredar di Indonesia melebihi dari jumlah penduduk Indonesia pada tahun 2013. Telepon seluler menggunakan gelombang elektromagnetik sebagai media penyalur data. Gelombang elektromagnetik termasuk gelombang tipe non-ionizing, dimana gelombang elektromagnetik tidak memiliki energi yang cukup kuat untuk memutus ikatan kimia pada sistem tubuh, Namun, penggunaan telepon seluler yang memancarkan gelombang elektromagnetik dalam intensitas yang tinggi dan jarak yang dekat dengan tubuh tetap dapat menimbulkan efek negatif pada tubuh. Gelombang elektromagnetik dapat meningkatkan jumlah radikal bebas. Peningkatan radikal bebas yang berlebihan dapat menyebakan stres oksidatif. Stres oksidatif dapat memicu peroksidasi lipid, yang dapat merusak membran sperma dan menurunkan kualitas sperma. Tujuan dari penulisan artikel ini adalah untuk mengetahui dampak dari gelombang elektromagnetik yang dipancarkan telepon seluler terhadap kualitas sperma. Metode yang digunakan adalah literature review dengan kriteria inklusi jurnal ilmiah internasional yang diakses melalui situs web terpercaya. Dari pencarian pada situs NCBI, Elsevier, Pubmed, dan situs lainnya, diperoleh 77 artikel yang sesuai kata kunci pada rentang waktu 2011-2020 dan sekitar 22 artikel yang dianggap relevan. Analisis dilakukan dengan metode systematic literature review dengan menelaah, mengidentifikasi, mengkaji, dan menyajikannya. Hasilnya adalah ditemukan berbagai penelitian yang menunjukkan bahwa ditemukan berbagai efek dari paparan gelombang elektromagnetik dari telepon seluler terhadap berbagai parameter sperma.
\end{abstract}

Kata kunci: kualitas sperma; telepon genggam; gelombang elektromagnetik

\section{EFFECT OF CELLPHONE ELECTROMAGNETIC WAVE ON SPERM QUALITY}

\begin{abstract}
Cellular phone usage is increasing every year. The number of cellular phones circulating in Indonesia exceeds the total population of Indonesia in 2013. Cellular phones use electromagnetic waves as a medium for carrying information. Electromagnetic waves are a nonionizing type of wave, where electromagnetic waves do not have enough energy to break chemical bonds in the body. However, prolonged use of cell phones that emit electromagnetic waves in high intensity and close proximity to the body can still cause negative effects on body. Electromagnetic waves can increase the number of free radicals. Excessive increase in free radicals can cause oxidative stress. Oxidative stress can trigger lipid peroxidation, which can damage sperm membranes and reduce sperm quality. The purpose of this article is to determine the effect of electromagnetic wave from cellular phoneon sperm quality. The method used is a literature review with the inclusion criteria of international scientific journals accessed through a trusted website. From searches on the NCBI, Elsevier, Pubmed, and other sites, we obtained 77 articles that match the keywords in 2011-2020 period and only about 22 articles that were considered relevant. The analysis was carried out using a systematic literature review method by
\end{abstract}


examining, identifying, assessing, and presenting it. The result is that various studies have shown that exposure of electromagnetic waves from cell phones can cause damage on various sperm parameters.

Keywords: cellphone; electromagnetic wave; sperm quality

\section{PENDAHULUAN}

Perkembangan zaman yang pesat menyebabkan meningkatkan penggunaan telepon seluler. Penggunaan telepon seluler tidak dapat dipisahkan dari kegiatan sehari-hari. Rata-rata penggunaan telepon seluler adalah 2 jam 51 menit perharinya (Comscore, 2016). Pada tahun 2013, jumlah telepon seluler yang beredar di Indonesia mencapai 240 juta buah, melebihi jumlah jumlah penduduk Indonesia yang berjumlah 237 juta jiwa berdasarkan sensus penduduk tahun 2010 (Kemkominfo, 2013). Telepon seluler menggunakan gelombang elektromagnetik untuk menyalurkan informasi. Walaupun radiasi yang dikeluarkan rendah, dengan paparan yang lama dan jarak yang dekat dengan sumber radiasi,gelombang elektromagnetik dapat menimbulkan efek buruk pada tubuh, terutama organ reproduksi pria (Sutyarso, 2010).

Pada populasi yang terkena paparan gelombang elektromagnetik kuat pada pekerjaannya ditemukan lebih banyak kejadian infertilitas dibandingkan kelompok yang tidak terpapar (Nabi et al., 2015). Ditambah lagi terdapat kebiasaan untuk meletakkan telepon seluler di saku celana yang letaknya berdekatan dengan organ reproduksi. Ditemukan penurunan kualitas sperma pada laki-laki yang memilliki kebiasaan meletakan telepon seluler di saku celana (Munasinghe, Weerasooriya, Liyanage, \& Wakkumbura, 2017)

Radiasi elektromagnetik terbagi menjadi dua tipe, yaitu tipe ionizing, contohnya gelombang $\mathrm{x}$ ray dan sinar gamma dan tipe non-ionizing, contohnya adalah gelombang radiofrekuensi. Gelombang yang dihasilkan telepon seluler adalah gelombang elektromagnetik tipe radiofrekuensi. Gelombang elektromagnetik dapat menimbulkan berbagai efek pada tubuh, antara lain efek termal, efek pada sawar darah otak, efek pada sistem syaraf, efek pada DNA dan struktur genetik dan efek pada sistem reproduksi (Om, 2019).

Organisasi internasional seperti International Commission on Non Ionizing Radiation Protection (ICNIRP) menetapkan batas radiasi gelombang elektromagnetik untuk publik dan untuk lingkungan kerja untuk melindungi masyarakat dari paparan berlebih dari gelombang elektromagnetik yang dihasilkan radiasi telepon seluler. Telepon seluler yang beredar dipasaran dirancang untuk tidak melampaui batas pemaparan gelombang elektromagnetik radiofrekuensi yang berdasarkan rekomendasi ICNIRP. Pedoman pemaparan gelombang elektromagnetik didasarkan pada Specific Absorbtion Rate (SAR), yang menunjukkan jumlah daya radiofrekuensi yang disserap dan mengendap di kepala atau tubuh saat perangkat melakukan transmisi. Uji tingkat SAR dilaksanakan pada posisi pengoperasian standar, dengan transmisi pada tingkat daya tertinggi yang disertifikasi di semua pita frekuensinya. Batas paparan radiasi gelombang elektromagnetik pada rentang $100 \mathrm{kHz}$ hingga $6 \mathrm{GHz}$ untuk masyarakat umum adalah $2.0 \mathrm{Watts} / \mathrm{kg}$ (Ziegelberger et al., 2020). 
Telepon seluler menggunakan frekuensi gelombang elektromagnetik berkisar pada rentang 900-1800 MHz. Frekuensi yang digunakan telepon seluler termasuk pada gelombang tipe nonionizing. Gelombang tipe non-ionizing tidak memiliki energi yang cukup untuk memutus ikatan kimia pada sistem tubuh. Namun, walaupun energi yang dikeluarkan dari gelombang elektromagnetik radiofrekuensi rendah, tetap ada efek negatif yang ditimbulkan. Gelombang elektromagnetik telepon seluler dapat meningkatkan kadar radikal bebas. Radikal bebas merupakan zat berupa atom atau molekul yang memiliki elektron tunggal atau elektron yang tidak berpasangan pada orbit terluarnya dan dapat berdiri sendiri. Reactive oxygen species (ROS) merupakan salah satu jenis radikal turunan dari oksigen yang dapat mengganggu kerja sistem biologis. ROS dalam tubuh dapat dinetralisasi oleh antioksidan. Ketika kadar ROS dalam tubuh lebih banyak dari antioksidan dan menyebabkan ketidakseimbangan antara ROS dan antioksidan makan dapat timbul stres oksidatif (Kesari, Kumar, \& Behari, 2011).

Stres oksidatif dapat menimbulkan peroksidasi lipid. Sel sperma mamalia memiliki komposisi lipid yang spesifik, termasuk multiple unsaturated fatty acid, plasminogen, dan sphingomyelins. Komposisis membran sperma yang kompleks tersebut bertanggung jawab atas kelenturan dan kemampuan fungsional sel sperma. Namun, lipid di dalam komposisi sel sperma rentan untuk teroksidasi. Peningkatan radikal bebas dapat menyebabkan teroksidasinya lipid yang merupakan penyusun dari membran plasma sperma. Terganggunya integritas membran sperma dapat menurunkan kualitas sperma, contohnya viabilitas dan motilitas sperma (Agarwal, Singh, Hamada, \& Kesari, 2011).

Berdasarkan pemaparan tersebut, terkait dengan hubungan gelombang elektromagnetik telepon seluler dengan kualitas sperma, maka penulis akan mengkaji apa saja dampak dari gelombang elektromagnetik yang digunakan oleh telepon seluler pada kualitas sperma melalui berbagai literatur.

\section{METODE}

Metode yang digunakan adalah literature review dengan langkah analitis meringkas topik dari berbagai sumber pustaka yang bertujuan untuk menambah pemahaman topik yang dibahas. Pengumpulan sumber data yang digunakan dalam artikel ini terdiri dari sumber data primer berupa jurnal ilmiah, baik nasional maupun internasional dan sumber tersier berupa situs web terpercaya. Penelusuran sumber data dilakukan melalui situs Pubmed, NCBI, dan situs lainnya. Kata kunci yang digunakan diantaranya cellphone, electromagnetic wave, sperm quality. Kriteria inklusi pada jurnal ini yaitu artikel dan jurnal ilmiah yang membahas tentang dampak dari gelombang elektromagnetik ponsel pada kualitas dari sperma. Melalui pencarian, diperoleh 77 artikel yang sesuai kata kunci pada rentang tahun 2011-2020 dan hanya sekitar 22 artikel yang dianggap relevan. Analisis dilakukan dengan metode systematic literature review yang dilakukan dengan cara menelaah, mengidentifikasi, mengkaji, dan menyajikannya. Sebelum proses penyajian, dilakukan penggabungan, pengkajian kembali materi yang diterangkan sebelumnya, dan pembandingan hasil yang disajikan artikel untuk selanjutnya penarikan kesimpulan yang sesuai. 
HASIL

Berbagai studi menunjukkan bahwa gelombang elektromagnetik dapat berpengaruh pada kualitas sperma dapat dilihat di tabel 1 .

Tabel 1.

Studi Mengenai Pengaruh Gelombang Elektromagnetik terhadap Kualitas Sperma

Subjek Jenis Paparan Temuan $\quad$ Sumber

\section{Penelitian}

\begin{tabular}{|c|c|c|c|}
\hline $\begin{array}{l}\text { Mencit } \\
\text { Swiss- } \\
\text { Albino } \\
\text { jantan }\end{array}$ & $\begin{array}{l}\text { Gelombang } \\
\text { radiofrekuensi } \\
902.4 \mathrm{MHz} \text { selama } 4 \text { / } \\
8 \text { jam/hari selama } \\
35 \text { hari }\end{array}$ & $\begin{array}{l}\text { Peningkatan sel } \\
\text { spermatogonium abnormal dan } \\
\text { penurunan jumlah spermatid. } \\
\text { Perubahan histologi dari } \\
\text { tubulus seminiferus. } \\
\text { Peningkatan kerusakan DNA. }\end{array}$ & $\begin{array}{l}\text { (Pandey, Giri, } \\
\text { Das, \& Upadhaya, } \\
\text { 2017) }\end{array}$ \\
\hline $\begin{array}{l}\text { Tikus putih } \\
\text { jantan galur } \\
\text { Sprague } \\
\text { Dawley }\end{array}$ & $\begin{array}{l}\text { Gelombang } \\
\text { radiofrekuensi } 900 \mathrm{MHz} \\
\text { selama } 1 \text { jam/hari } \\
\text { selama } 30 \text { hari. }\end{array}$ & $\begin{array}{l}\text { Peningkatan apoptosis dan } \\
\text { perubahan kadar antioksidan }\end{array}$ & $\begin{array}{l}\text { (Odaci \& } \\
\text { Özyilmaz, 2015) }\end{array}$ \\
\hline Manusia & $\begin{array}{l}\text { Gelombang } \\
\text { radiofrekuensi 900- } \\
1800 \mathrm{MHz}\end{array}$ & $\begin{array}{l}\text { Peningkatan fragmentasi DNA } \\
\text { secara signifikan dan } \\
\text { peningkatan jumlah sperma } \\
\text { yang motilitasnya non } \\
\text { progresif }\end{array}$ & $\begin{array}{l}\text { (Gorpinchenko, } \\
\text { Nikitin, Banyra, } \\
\text { \& Shulyak, 2014) }\end{array}$ \\
\hline $\begin{array}{l}\text { Tikus } \\
\text { jantan galur } \\
\text { Sprague } \\
\text { Dawley }\end{array}$ & $\begin{array}{l}\text { Gelombang } \\
\text { radiofrekuensi telepon } \\
\text { seluler dengan SAR } \\
1,56.1 \& 3 \text { jam/hari } \\
\text { selama } 21 \text { hari. }\end{array}$ & Penurunan motilitas sperma & $\begin{array}{l}\text { (Wulan, Maria } \\
\text { Victoria, \& Ratna, } \\
\text { 2015) }\end{array}$ \\
\hline $\begin{array}{l}\text { Tikus } \\
\text { jantan galur } \\
\text { Wistar }\end{array}$ & $\begin{array}{l}\text { Gelombang } \\
\text { radiofrekuensi } \\
1910.5 \mathrm{MHz} \text { selama } \\
60 \text { hari, } 2 \text { jam per hari. }\end{array}$ & $\begin{array}{l}\text { Penurunan signifikan jumlah } \\
\text { sperma, diameter tubulus } \\
\text { seminiferus, berat testis, dan } \\
\text { peningkatan MDA. }\end{array}$ & $\begin{array}{l}\text { (Kumar, Nirala, } \\
\text { Behari, \& Paulraj, } \\
\text { 2014) }\end{array}$ \\
\hline $\begin{array}{l}\text { Tikus } \\
\text { jantan galur } \\
\text { Wistar }\end{array}$ & $\begin{array}{l}\text { Gelombang radio } \\
\text { frekuensi telepon } \\
\text { seluler GSM } 900 \mathrm{MHz} \text {. } \\
2 \text { jam/hari selama } \\
45 \text { hari }\end{array}$ & $\begin{array}{l}\text { Penurunan jumlah sperma, } \\
\text { peningkatan apoptosis, } \\
\text { mikronuklei, dan ROS. Ada } \\
\text { efek pada tingkatan } \\
\text { antioksidan dan jumlah } \\
\text { testosteron. sperm count, } \\
\text { increased apoptosis, } \\
\text { micronuclei and ROS. }\end{array}$ & $\begin{array}{l}\text { (Kesari \& Behari, } \\
\text { 2012) }\end{array}$ \\
\hline $\begin{array}{l}\text { Tikus } \\
\text { jantan galur } \\
\text { Wistar }\end{array}$ & $\begin{array}{l}\text { Gelombang } \\
\text { radiofrekuensi 900MHz } \\
2 \text { jam/ hari selama } \\
35 \text { hari }\end{array}$ & $\begin{array}{l}\text { Penurunan secara signifikan } \\
\text { dari aktivitas protein kinase C, } \\
\text { jumlah sperma dan } \\
\text { peningkatan apoptosis sel } \\
\text { sperma. }\end{array}$ & $\begin{array}{l}\text { (Kesari \& Behari, } \\
\text { 2010) }\end{array}$ \\
\hline $\begin{array}{l}\text { Tikus } \\
\text { jantan galur } \\
\text { Wistar }\end{array}$ & $\begin{array}{l}\text { Gelombang } \\
\text { radiofrekuensi } \\
900 \mathrm{MHz} 1 \text { jam/hari } \\
\text { selama } 3 \text { bulan }\end{array}$ & $\begin{array}{l}\text { Penurunan kadar testosterone } \\
\text { serum }\end{array}$ & $\begin{array}{l}\text { (Meo, Al-Drees, } \\
\text { Husain, Khan, \& } \\
\text { Imran, 2010) }\end{array}$ \\
\hline
\end{tabular}


Tabel 2.

Parameter Kualitas Sperma

\begin{tabular}{lc}
\hline \multicolumn{1}{c}{ Parameter } & Batas Bawah \\
\hline $\begin{array}{l}\text { Makroskopik } \\
\text { Volume semen }(\mathrm{mL})\end{array}$ & $1,5(1,4-1,7)$ \\
\hline $\mathrm{pH}$ & $>7,2$ \\
\hline Warna & Normal = putih keabu abuan \\
\hline Bau & Normal =khas \\
\hline Mikroskopik & $39(33-46)$ \\
Jumlah sperma total $\left(10^{6}\right.$ per ejakulat) & $15(12-16)$ \\
\hline Konsentrasi sperma $\left(10^{6}\right.$ per $\left.\mathrm{mL}\right)$ & $40(38-42)$ \\
\hline Motilitas total $(\%)$ & $32(31-34)$ \\
\hline Motilitas progresif $(\%)$ & $58(55-63)$ \\
\hline Viabilitas $(\%)$ & $4(3,0-4,0)$ \\
\hline Morfologi sperma $(\%)$ & $<1,0$ \\
\hline Kimia & $>13$ \\
Leukosit peroksidase positif $\left(10^{6}\right.$ per $\left.\mathrm{mL}\right)$ & \\
\hline Fruktosa seminal $(\mu \mathrm{mol} /$ ejakulat) &
\end{tabular}

Sumber : (Duarsa et al., 2015)

\section{PEMBAHASAN}

Reproduksi merupakan salah satu ciri makhluk hidup. Walaupun sistem reproduksi tidak berkontribusi pada homeostasis tubuh dan kurang esensial untuk kebertahanan hidup seorang manusia, namun sistem reproduksi tetap memegang peran penting dalam kehidupan seorang manusia, seperti kontribusi yang signifikan pada tingkah laku psikososial manusia dimana manusia bertingkah sebagai makhluk seksual dan berperan penting pada bagaimana manusia melihat dirinya sendiri dan bagaimana manusia berinteraksi dengan sesamanya. Reproduksi manusia memastikan kelangsungan hidup dari spesies manusia (Sherwood, 2016). Organ yang paling penting dari sistem reproduksi adalah gonad, yaitu testis pada pria dan ovarium pada wanita. Pada kedua jenis kelamin, gonad yang telah dewasa melakukan fungsi ganda, yaitu memproduksi gamet dengan proses gametogenesis dan mensekresikan hormon seks. Fungsi yang pertama adalah gametogenesis. Gametogenesis pada pria berupa spermatogenesis, yaitu pembuatan sel sperma, dan gametogenesis pada wanita ada oogenesis, yaitu pembuatan ovum atau sel telur(Costanzo, 2014).

Spermatogenesis atau proses pembentukan sel sperma berlangsung sepanjang tubulus seminiferus yang terletak didalam testis dan prosesnya terbagi menjadi 3 fase, yaitu fase proliferasi mitotik, fase pembelahan meiosis, dan fase spermiogenesis. Pada fase proliferasi mitotik, spermatogonium akan bermitosis. Hasil mitosis dari spermatogonium berupa anakan sel akan berjumlah 46 kromosom yang identik dengan induknya. Salah satu sel anakan akan bermitosis sebanyak dua kali sehingga terbentuk empat spermatosit primer. Pada fase kedua, yaiu fase pembelahan meiosis, setiap spermatosit primer yang memiliki jumlah 46 kromosom rangkap akan membentuk dua spermatosit sekunder yang masing-masing memiliki jumlah haploid 23 kromosom rangkap selama pembelahan meiosis pertama. 
Pembelahan meiosis kedua, terbentuk anakan berupa empat spermatid yang masing-masingnya memiliki 23 kromosom tunggal (Sherwood, 2016). Tahap ketiga adalah tahap spermiogenesis. Tahap ini adalah tahap dimana spermatid akan berkembang menjadi spermatozoa. Tidak ada pembelahan sel yang terjadi saat fase spermiogenesis, setiap spermatid akan berubah menjadi satu sel sperma. Pada proses ini, spermatid yang berbentuk kebulatan akan berubah menjadi sperma yang berbentuk oval dan ramping, lalu diatas nukleus akan terbentuk akrosom yang berbentuk memanjang, selain itu flagellum akan terbentuk, sel sertoli akan membuang sitoplasma yang tidak diperlukan, dan mitokondria bertambah banyak. Pada akhirnya, terjadi proses spermiasi, dimana sperma akan melepaskan diri dari sel sertoli dan memasuli lumen tubulus seminiferus. Sel sertoli kemudian mensekresikan cairan yang akan mendorong sperma ke duktus testis (Tortora \& Derrickson, 2014).

Cara untuk mengetahui kualitas sperma seseorang sebagai penilaian potensi kesuburan pria dapat dilakukan dengan cara analisis sperma atau pemeriksaan sperma. Pemeriksaan sperma dilakukan secara makroskopis, mikroskopis, dan secara kimia. Pada pemeriksaan makroskopik, parameter yang diperiksa adalah warna, bau, kekentalan, volume dan $\mathrm{pH}$. Pada pemeriksaan mikroskopik dilakukan pemeriksaan motilitas progresif, motilitass total, viabilitas, morfologi normal, dan konsentrasi sperma. Pada pemeriksaan kimia dilakukan pemeriksaan fruktosa semen (Duarsa et al., 2015). Pada tabel 2, terdapat parameter-parameter yang diuji pada analisis sperma
Gelombang elektromagnetik merupakan gelombang yang terbentuk dari medan magnet dan medan listrik. Salah satu alat yang menggunakan gelombang elektromagnetik sebagai media transmisi adalah telepon seluler. Gelombang elektromagnetik yang digunakan oleh telepon seluler masuk dalam spektrum radiofrekuensi. Paparan gelombang elektromagnetik dapat menimbulkan kerusakan struktur dan fungsi dari sel Leydig. Sel Leydig yang rusak secara struktur dan fungsi menyebabkan turunnya produksi dari testosteron. Penurunan testosteron dapat menurunkan kualitas sperma, karena testosteron berperan dalam proses spermatogenesis, formasi spermatozoa, dan pemeliharaan morfologi dan fisiologi dari tubulus seminiferus (Kesari, Agarwal, \& Henkel, 2018).

Selain merusak struktur dan fungsi sel Leydig, gelombang elektromagnetik juga dapat meningkatkan jumlah ROS dalam tubuh. Tingginya konsentrasi ROS menimbulkan hialngnya keseimbangan antara antioksidan dan ROS. Ketidakseimbangan ROS dan antioksidan akan menimbulkan stres oksidatif. Stres oksidatif pada organ reproduksi laki-laki dapat menyebabkan kerusakan DNA dan peroksidasi lipid. Sel sperma mamalia tersusun dari komposisi lemak yang kompleks dan spesifik, antara lain multiple unsaturated fatty acid, plasminogen, dan sphingomyelins. Komposisi membran sperma yang kompleks tersebut memiliki andil dalam kelenturan dan kemampuan fungsional sel sperma. Namun, lipid di dalam komposisi sel sperma mudah untuk teroksidasi. Paparan gelombang elektromagnetik yang dipancarkan telepon seluler menyebabkan penurunan kualitas sperma seperti konsentrasi sperma dan viabilitas sperma (Houston, 
Nixon, King, De Iuliis, \& Aitken, 2016).

Gelombang elektromagnetik dapat meningkatkan ROS yang jika jumlahnya melebihi antioksidan yang tersedia dalam tubuh dapat menyebabkan stres oksidatif. Stres oksidatif menyebabkan proses peroksidasi lipid pada membran sel sperma sehingga permeabilitas membran sel meningkat. Peningkatan permeabilitas membran sperma memyebabkan terganggunya homeostasis ion kalsium pada sel, sehingga terjadi deplesi ion kalsium bersama dengan makromolekul lainnya seperti ATP dari dalam sel sperma. ATP dan ion kalsium dalam sel sperma diperlukan untuk motilitas spermatozoa. Ion kalsium juga dibutuhkan sebagai aktivator protein kinase $\mathrm{C}$ (PKC) yang terletak di flagel sperma yang berfungsi untuk pengaturan motilitas sperma. Terganggunya homeostasis ion kalsium menyebabkan PKC tidak berfungsi secara optimal, dan dapat mengganggu salah satu parameter kualitas sperma yaitu motilitas sperma (Agarwal, 2011)

\section{SIMPULAN}

Ketergantungan kegiatan sehari-hari manusia dengan telepon seluler menyebabkan tingginya penggunaan telepon seluler. Telepon seluler memiliki antena yang dapat memancarkan gelombang elektromagnetik sebagai media untuk transfer informasi. Pada penelitian ini ditemukan berbagai studi yang menunjukkan berbagai parameter sperma yang terpengaruh dari paparan gelombang elektromagnetik yang dipancarkan oleh telepon seluler.

\section{DAFTAR PUSTAKA}

Agarwal, A. (2011). Cell Phones and their Impact on Male Fertility: Fact or Fiction. The Open Reproductive Science Journal, 3(1), 125-137. https://doi.org/10.2174/18742556 01103010125

Agarwal, A., Singh, A., Hamada, A., \& Kesari, K. (2011). Cell phones and male infertility: A review of recent innovations in technology and consequences. International Braz J Urol. https://doi.org/10.1590/S167755382011000400002

Costanzo, L. S. (2014). Physiology, Fifth Edition. Saunders, an imprint of Elsevier Inc.

Duarsa, G. W. K., Soebadi, D. M., Taher, A., Purnomo, B. B., Rasyid, N., Noegroho, B. S., ... Rizaldi, F. (2015). Guideline Infertilitas Pria 2015. Ikatan Ahli Urologi Indonesia.

Ghanbari, M., Mortazavi, S. B., Khavanin, A., \& Khazaei, M. (2013). The effects of cell phone waves (900 MHz-GSM Band) on sperm parameters and total antioxidant capacity in Rats. International Journal of Fertility and Sterility.

Gorpinchenko, I., Nikitin, O., Banyra, O., \& Shulyak, A. (2014). The influence of direct mobile phone radiation on sperm quality. Central European Journal of Urology. https://doi.org/10.5173/ceju.2014. 01.art14

Houston, B. J., Nixon, B., King, B. V., De Iuliis, G. N., \& Aitken, R. J. (2016). The effects of 
radiofrequency electromagnetic radiation on sperm function. Reproduction. https://doi.org/10.1530/REP-160126

Kesari, K. K., Agarwal, A., \& Henkel, R. (2018). Radiations and male fertility. Reproductive Biology and Endocrinology. BioMed Central Ltd. https://doi.org/10.1186/s12958018-0431-1

Kesari, K. K., \& Behari, J. (2010). Microwave exposure affecting reproductive system in male rats. Applied Biochemistry and Biotechnology. https://doi.org/10.1007/s12010009-8722-9

Kesari, K. K., \& Behari, J. (2012). Evidence for mobile phone radiation exposure effects on reproductive pattern of male rats: Role of ROS. Electromagnetic Biology and Medicine. https://doi.org/10.3109/15368378. 2012.700292

Kesari, K. K., Kumar, S., \& Behari, J. (2011). Effects of radiofrequency electromagnetic wave exposure from cellular phones on the reproductive pattern in male Wistar rats. Applied Biochemistry and Biotechnology, 164(4), 546559.

https://doi.org/10.1007/s12010010-9156-0

Kumar, S., Nirala, J. P., Behari, J., \& Paulraj, R. (2014). Effect of electromagnetic irradiation produced by $3 \mathrm{G}$ mobile phone on male rat reproductive system in a simulated scenario. Indian Journal of Experimental Biology.
Meo, S. A., Al-Drees, A. M., Husain, S., Khan, M. M., \& Imran, M. B. (2010). Effects of mobile phone radiation on serum testosterone in Wistar albino rats. Saudi Medical Journal.

Munasinghe, D. A. L., Weerasooriya, M. K. B., Liyanage, J. A., \& Wakkumbura, H. P. (2017). Effect Of Carrying Cell Phones In Trouser Pockets, On Semen Parameter. Journal of International Research in Medical and Pharmaceutical Sciences, 12(2), 33-38.

Odaci, E., \& Özyilmaz, C. (2015). Exposure to a $900 \mathrm{MHz}$ electromagnetic field for 1 hour a day over 30 days does change the histopathology and biochemistry of the rat testis. International Journal of Radiation Biology. https://doi.org/10.3109/09553002. 2015.1031850

Om, J. (2019). The Effects of Cell Phone Radiation on the Human Body: An Overview. European Journal of Engineering Research and Science, 4(3), 166-169. https://doi.org/10.24018/ejers.201 9.4.3.1192

Pandey, N., Giri, S., Das, S., \& Upadhaya, P. (2017). Radiofrequency radiation (900 $\mathrm{MHz}$ )-induced DNA damage and cell cycle arrest in testicular germ cells in swiss albino mice. Toxicology and Industrial Health. https://doi.org/10.1177/07482337 16671206

Sherwood, L. (2016). Human physiology from cells to systems Ninth Edition. Appetite.

Sutyarso. (2010). Hubungan antara 
Lama Menggunakan Ponsel

dengan Jumlah dan Kualitas

Spermatozoa pada Laki-laki

Fertil. Majalah Kedokteran

Indonesia, 60(3), 119-125.

Retrieved from

https://www.researchgate.net/publ ication/312282609_Hubungan_an tara_Lama_Menggunakan_Ponsel _dengan_Jumlah_dan_Kualitas_S permatozoa_pada_Laki-

laki_Fertil_Sutyarso

Tortora, G. J., \& Derrickson, B. (2014). Principles of Anatomy \& Physiology 14th Edition. Wiley.

Wulan, A. J., Maria Victoria, R., \& Ratna, M. G. (2015). Pengaruh Paparan Gelombang Elektromagnetik Handphone terhadap Jumlah dan Motilitas Spermatozoa Tikus Putih Jantan (Rattus norvegicus) Galur Sprague dawley. Jurnal Majority, 4(9), 1-7. Retrieved from https://juke.kedokteran.unila.ac.id /index.php/majority/article/view/1 395

Ziegelberger, G., Croft, R., Feychting, M., Green, A. C., Hirata, A., d'Inzeo, G., ... Watanabe, S. (2020). Guidelines for limiting exposure to electromagnetic fields $(100 \mathrm{kHz}$ to $300 \mathrm{GHz})$. Health Physics. Lippincott Williams and Wilkins.

https://doi.org/10.1097/HP.00000

00000001210 
Jurnal Penelitian Perawat Profesional, Volume 3 No 1 Hal 71 - 80, Februari 2021 Global Health Science Group 